\title{
Advanced Space Suit Insulation Feasibility Study
}

\author{
Luis A. Trevino and Evelyne S. Orndoff \\ NASA Johnson Space Center
}

\section{ABSTRACT}

For planetary applications, the space suit insulation has unique requirements because it must perform in a dynamic mode to protect humans in the harsh dust, pressure and temperature environments. Since the presence of a gaseous planetary atmosphere adds significant thermal conductance to the suit insulation, the current multi-layer flexible insulation designed for vacuum applications is not suitable in reduced pressure planetary environments such as that of Mars. Therefore a feasibility study has been conducted at NASA to identify the most promising insulation concepts that can be developed to provide an acceptable suit insulation. Insulation concepts surveyed include foams, microspheres, microfibers, and vacuum jackets. The feasibility study includes a literature survey of potential concepts, an evaluation of test results for initial insulation concepts, and a development philosophy to be pursued as a result of the initial testing and conceptual surveys. The recommended focus is on microfibers due to the versatility of fiber structure configurations, the wide choice of fiber materials available, the maturity of the fiber processing industry, and past experience with fibers in insulation applications.

\section{INTRODUCTION}

HEAT BALANCE FOR SUITED CREWMEMBER To better understand the effect of insulation on the suited crewmember, an overall heat balance must first be presented, along with a breakdown of the individual heat contributions. Figure 1 shows the overall heat balance terms. The heat input term is the heat generated within the crewmember enclosure, or Qgen, consisting of metabolic heat and equipment loads. Heat output terms are the heat removed by the thermal control system, or Qtcs, and the heat lost to the environment through the insulation and suit enclosure, or Qsuit-leak.
The heat loads can further be sub-divided into individual thermal environment contributions, as shown in Figure 2. Here the Qsuit-leak term has been replaced by three terms. The absorbed thermal radiation, or Qabs, is that due to the net solar and infrared radiation absorbed by the outer surfaces of the EMU. Of importance in this term are the solar absorption property, $\alpha$, and the infrared absorption property, $\varepsilon$, of the outer suit materials. A second term is the emitted radiation from the suit surface, or Qemitted, which also involves the infrared absorption property $\varepsilon$. Finally, in a gaseous environment such as on Mars, a third term is the heat lost to the gas, or Qlost-to-gas. The gas term in turn

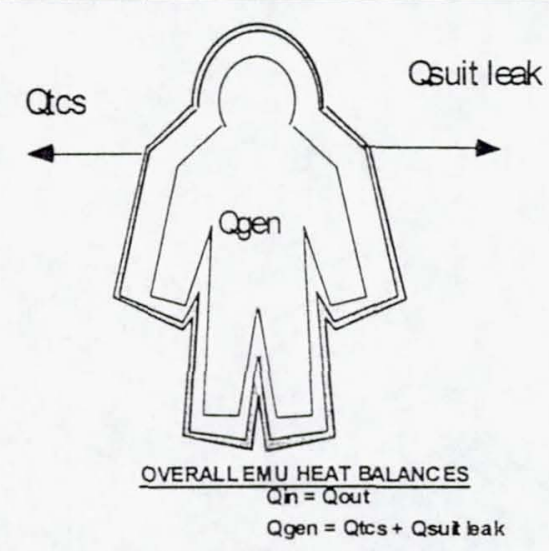

Figure 1. Heat Balance Model

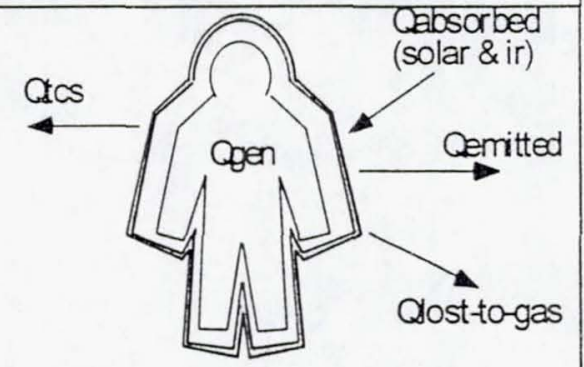

EMU IN MARS ENVRONMENT

Qgen + Qabs = Q $\mathrm{ks}+$ Qemitied + Qlost to gas

Qabs $=\left(\alpha^{*} Q_{\text {sol }}+\varepsilon^{*} Q_{r}\right)^{*}$ Asut

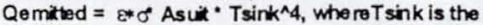
radia fon sink, $\varepsilon \& \sigma$ are the suit emis sivity and $S$ iephan Bditeman constant, resp.

Figure 2. Environment Heat Loads 
includes the heat lost through free convection in a gravity environment, and that lost by forced convection from wind currents.

From the simplifying relations in figures 1 and 2 , it is possible to calculate the heat lost through the suit insulation. However, because the thermal radiation terms involve temperature raised to the fourth power, solution of the heat leak usually requires an iterative solution using computer thermal analyzers. The absorbed heat and the emitted heat terms are solved by an environment thermal analyzer program that includes multiple suit and environment surfaces. For initial thermal studies, approximate methods based on results previously obtained from thermal analyzer outputs were used to determine heat leak requirements and insulation performance requirements.

INSULATION REQUIREMENTS IN REDUCED PRESSURE - Since the present study is for space suit application in reduced pressure environments, the environment of Mars is the primary concern. Compared to the requirements in a hard vacuum environment such as low earth orbit and the moon, the insulation requirements are more severe for Mars application because of the presence of an atmosphere. Due to the presence of gas convection and conduction cooling, conventional multi-layer insulation (MLI) is almost useless in the cold environments of Mars. The current multi-layer insulation was designed to be used in vacuum only, where only conduction and radiation heat transfer are significant.

For Mars, four possible EVA thermal environments were reviewed from sites on Mars (see Figure 3). Of these, the two nominal thermal EVA sites

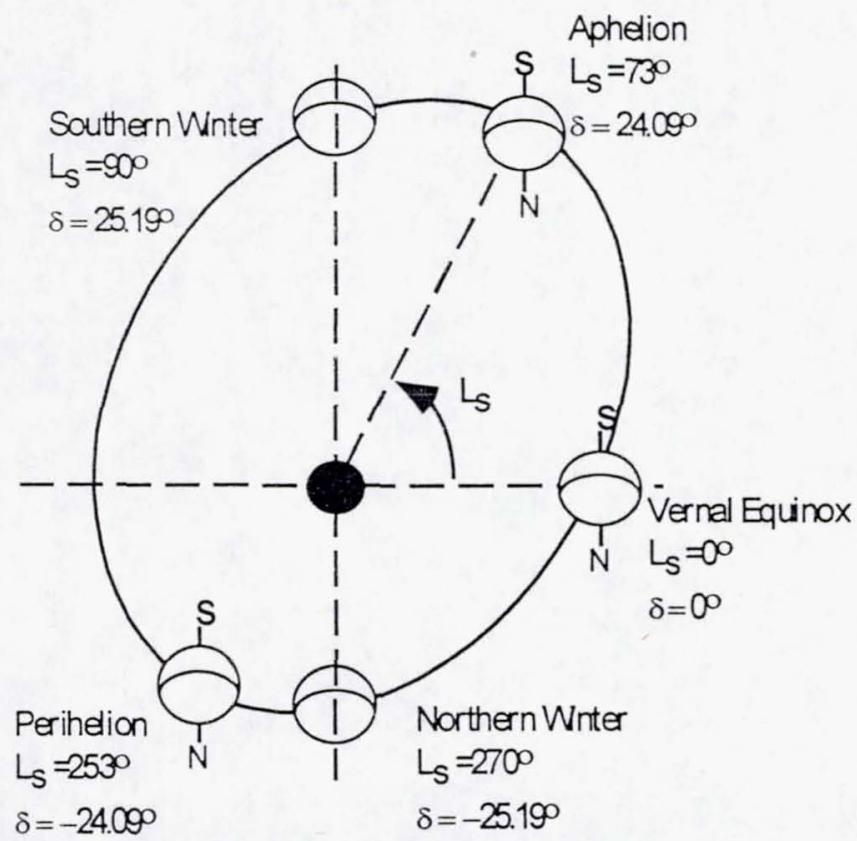

Figure 3
Geometry of the Martian Orbit selected were a Southern Winter site at solar longitude of $90^{\circ}$, and a Southern site at solar longitude of $253^{\circ}$. Table 1 from [1] shows the Mars environment and space suit thermal parameters for these longitudes at a typical landing site, the Candor region. For the hot Martian environment, both the suit radiation sink and the atmospheric surface temperature are very nominal and not a concern for the suit. For the cold environment, however, these temperatures are very cold $(211$ to $227 \mathrm{~K}, 189$ to $227 \mathrm{~K}$, suit radiative sink and atmosphere, respectively) and require special protection.

Table 1

Mars Environment and Space Suit Thermal Parameters for Candor Region

\begin{tabular}{|c|c|c|}
\hline & $\begin{array}{l}\text { HOT ENVIRONMENT, } \\
\text { SOLAR } \\
\text { LONGITUDE (LS) }=253 \\
\text { DEG }\end{array}$ & $\begin{array}{l}\text { COLD NOMINAL ENVIR., } \\
\text { SOLAR LONGITUDE } \\
(\mathrm{LS})=90 \mathrm{DEG}\end{array}$ \\
\hline $\begin{array}{l}\text { LOCATION } \\
\text { (LATITUDE, } \\
\text { LONGITUDE) }\end{array}$ & $8 \mathrm{~S} ; 75 \mathrm{~W}$ & $8 \mathrm{~S}, 75 \mathrm{~W}$ \\
\hline $\begin{array}{l}\text { ATMOS.I } \\
\text { SURFACE } \\
\text { TEMP }\end{array}$ & $\begin{array}{l}219 \text { TO } 300 \mathrm{~K} \\
\text { (65 TO } 80 \mathrm{~F})\end{array}$ & $\begin{array}{l}189 \text { TO } 227 \mathrm{~K} \\
(-120 \text { TO }-50 \mathrm{~F})\end{array}$ \\
\hline SKY TEMP & $142 \mathrm{~K} \quad(-203 \mathrm{~F})$ & $142 \mathrm{~K} \quad(-203 \mathrm{~F})$ \\
\hline $\begin{array}{l}\text { SUIT SINK } \\
\text { TEMP } \\
\text { RADIATOR } \\
\text { SINK TEMP }\end{array}$ & $\begin{array}{r}264 \text { TO } 269 \mathrm{~K} \\
\text { (15 TO 25 F) } \\
252 \text { TO } 266 \mathrm{~K} \\
(-5 \text { TO 20 F) }\end{array}$ & $\begin{array}{l}211 \text { TO } 227 \mathrm{~K} \\
(-80 \text { TO }-50 \mathrm{~F}) \\
177 \text { TO } 205 \mathrm{~K} \\
(-150 \text { TO }-90 \mathrm{~F})\end{array}$ \\
\hline $\begin{array}{l}\text { ATMOS. } \\
\text { PRESS. }\end{array}$ & (7.5 TORR) & (6.4 TORR) \\
\hline $\begin{array}{l}\text { WIND SPEED } \\
\text { (M/S) }\end{array}$ & 20 & 10 \\
\hline
\end{tabular}

From analysis of a simplified suit thermal model and from the requirements in Table 1 , a maximum conductance of $0.62 \mathrm{~W} / \mathrm{m} 2-\mathrm{K}$ through the suit insulation was selected for testing and further analyses in cold environments. Using a goal of $12.7 \mathrm{~mm}$ (0.5 inch) insulation thickness, this results in a maximum thermal conductivity of $7.9 \mathrm{~mW} / \mathrm{m}-\mathrm{K}$, with $5 \mathrm{~mW} / \mathrm{m}-\mathrm{K}$ being a reasonable goal to compensate for thermal shorts from stitched seams and compressed insulation layers.

\section{SURVEY OF CANDIDATE INSULATION CONCEPTS}

Numerous insulation concepts were reviewed for possible space suit application. These include porous materials (foams, microspheres, microfibers), phase change materials, hollow spheres, solvent-gas elements, and vacuum enclosures. MLI with reflective surfaces was not reviewed as a primary insulation structure, but it may still be used to enhance thermal properties of any of the candidates reviewed.

POROUS STRUCTURES FOR MARS LANDERS Porous insulation structures for Mars landers were reviewed in an ICES paper presented in 1993 [2]. The purpose was to obtain data and analytical models for Mars surface station thermal insulators. Analytical and experimental data was obtained for silica hollow spheres, $(<40 \mu \mathrm{m}$ diameter) and microfibers $(2 \mu \mathrm{m}$ diameter). Results on thermal conductivity were 10 to 
$15 \mathrm{~mW} / \mathrm{m}-\mathrm{K}$ for fibers at Mars pressure, with higher values for spheres due to landing impact requirements.

The structure selected for the surface station consists of a silica fiber felt enclosed between two layers of coated woven glass fabric which contain and seal the fibers from external contamination. These structures cannot be easily integrated in a space suit due to thermal performance risks and safety risks. Thermal protection degradation will result when glass fibers are broken from repeated cycling as is required in a space suit. Medical hazards can result from loose fibers that may penetrate through suit fabrics.

PHASE CHANGE MATERIALS - Phase change materials (PCM) can have an insulating effect for a limited amount of time. For suit application, two types of phase change materials were evaluated. The first was an active phase change material (PCM) called K-Max, from Rasor Associates, Inc., Sunnyvale, $\mathrm{Ca}$. This structure conducts heat by evaporation and condensation of a working fluid, similar to a heat pipe. Interconnecting pores are filled with a liquid, such as butane in one design, and the conductivity can be changed by pressure variation within the pores.

Although plastic and ceramic materials are acceptable for an active PCM design, current designs are not flexible enough for suit application. In addition, the presence of a toxic working fluid and the need for pressure control create safety and maintainability issues.

A second type of PCM evaluated was passive. Many materials have been reviewed in the past for suit application, as seen in Table (2). However, there is narrow range of passive materials that exhibit high latent heat of fusion at or near suit temperatures. Other disadvantages of passive PCM's are high weight and volume, regeneration requirements, flammability, and toxic issues.

HOLLOW SPHERES - Various hollow ceramic spheres were surveyed from industry applications. An example is $3 \mathrm{M}$ Scotchlite glass spheres with a high strength to weight ratio, a diameter of less than $177 \mu$, and thermal conductivity between 60 to $200 \mathrm{~mW} / \mathrm{m}-\mathrm{K}$ ( 0.4 to $1.4 \mathrm{Btu} /$-in/hr-ft2-F) at $0 \mathrm{C}(32 \mathrm{~F})$. Advantages of spheres are that they can be filled with a low pressure gas to reduce heat transfer, they roll over each other easily to allow for flexible insulation, and they pack tightly together to increase effective insulation volume. Disadvantages include possible breakage, lack of cohesiveness, and uneven distribution of spheres (clumping). Because of the high development required in a suit application, spheres were not ranked high.

SOLUBLE GAS ELEMENTS - A novel idea proposed by [3] allows variation of thermal insulation properties through the use of a solvent-gas system. In one concept, a fabric made of hollow filaments can be woven. The hollow filaments contain a gas and solvent material. At higher temperatures, the gas solubility of the solution increases, followed by dissolving of additional gas which in turn deflates the hollow elements. The deflation results in higher thermal conductivity due to shorter thermal paths.

Table 2. PASSIVE PHASE CHANGE MATERIALS SURVEYED

\begin{tabular}{|c|c|c|c|c|c|c|}
\hline NAME & $\begin{array}{c}\text { MELT } \\
\text { POINTI } \\
\text { FUSION } \\
\text { K } \\
\text { (F) }\end{array}$ & $\begin{array}{c}\text { LATENT } \\
\text { HEAT } \\
\text { OF FUSION } \\
\text { CALMOLE } \\
\text { (BTU/LB) }\end{array}$ & $\begin{array}{c}\text { STORAGE } \\
\text { PER } \\
\text { UNIT } \\
\text { VOLUME } \\
\\
\text { (BTU/IN3) }\end{array}$ & \begin{tabular}{|c|} 
SPECIFIC \\
HEAT \\
CALMOL- \\
$K$ \\
$(B T U / L B-$ \\
F)
\end{tabular} & $\begin{array}{l}\text { DENSITY } \\
\text { (LB/FT3) }\end{array}$ & $\begin{array}{l}\mathrm{S} \\
\mathrm{O} \\
\mathrm{U} \\
\mathrm{R} \\
\mathrm{C} \\
\mathrm{E}\end{array}$ \\
\hline N-PENTADECANE & $\begin{array}{c}283 \\
(49.9)\end{array}$ & $\begin{array}{l}8268 \\
(70.1)\end{array}$ & 1.9 & $\begin{array}{c}157 \\
(0.741)\end{array}$ & $(46.8)^{*}$ & 1 \\
\hline N-TETRADECANE & $\begin{array}{c}279 \\
(42.6)\end{array}$ & $\begin{array}{l}10772 \\
(97.7)\end{array}$ & 2.6 & $\begin{array}{c}85.82 \\
(0.433)\end{array}$ & $(46.5)^{*}$ & 1 \\
\hline N-HEXADECANE & $\begin{array}{c}291 \\
(64.7) \\
\end{array}$ & $\begin{array}{r}12753 \\
(101.4)\end{array}$ & 2.8 & $\begin{array}{l}101.51 \\
(0.449)\end{array}$ & $(47.1)^{*}$ & 1 \\
\hline $\begin{array}{l}\text { N-PENTADECANE } \\
\text { (SOLID-SOLID) }\end{array}$ & $\begin{array}{c}\text { Transition To } \\
\text { Crystalline } \\
\text { Phases (28F) }\end{array}$ & $\begin{array}{c}\text { HtOfTransiti } \\
\text { on } \\
2191 \\
(18.6)\end{array}$ & & & & 1 \\
\hline $\begin{array}{l}\text { KHF2 } \\
\text { SOLUTION(20\%) }\end{array}$ & $(17.6)$ & (155) & (5.9) & & 65.8 & 2 \\
\hline WATER & (32) & $(143.5)$ & $(5.13)$ & & 61.8 & 2 \\
\hline FORMIC ACID & (46) & $(106)$ & (4.7) & & 76.6 & 2 \\
\hline $\mathrm{LiNO} 3.3 \mathrm{H} 2 \mathrm{O}$ & (86) & $(128)$ & $(7.12)$ & & 96.1 & 2 \\
\hline GALLIUM & (86) & $(34.4)$ & $(7.58)$ & & 380.8 & 2 \\
\hline $\mathrm{NaHPO} 4.12 \mathrm{H} 2 \mathrm{O}$ & (97) & (114) & (6.6) & & 100 & 2 \\
\hline ELAIDIC ACID & $(117)$ & $(93.7)$ & $(2.88)$ & & 53.1 & 2 \\
\hline $\mathrm{Na} 2 \mathrm{~S} 2 \mathrm{O} 3.5 \mathrm{H} 2 \mathrm{O}$ & $(120)$ & (86) & $(5.09)$ & & 102.3 & 2 \\
\hline $\mathrm{NaOH} \cdot \mathrm{H} 2 \mathrm{O}$ & $(147)$ & $(117)$ & $(7.38)$ & & 109 & 2 \\
\hline $\begin{array}{l}\text { CERROBEND } \\
\text { ALLOY }\end{array}$ & $(158)$ & $(14)$ & (4.73) & & 583.8 & 2 \\
\hline $\mathrm{Bas}(\mathrm{OH}) 2-8 \mathrm{H}_{2} \mathrm{O}$ & $(172)$ & $(129)$ & $(10.15)$ & & 136 & 2 \\
\hline ACETAMIDE & $(178)$ & (104) & $(4.36)$ & & 72.4 & 2 \\
\hline $\begin{array}{l}\text { METHYL } \\
\text { FUMARATE }\end{array}$ & (222) & $(104)$ & $(6.77)$ & & 112.5 & 2 \\
\hline
\end{tabular}

SOURCE1: Allied Signal-AiResearch, EVA Systems Anaiysis. 9164783, Nov 1991 SOURCE2: system conceptual Study Report For The RNTS, NAS9-16509, Ham Std, Dec82 NOTE: English values not in parenthesis are calculated from given data. "Density at $120 \mathrm{~F}$

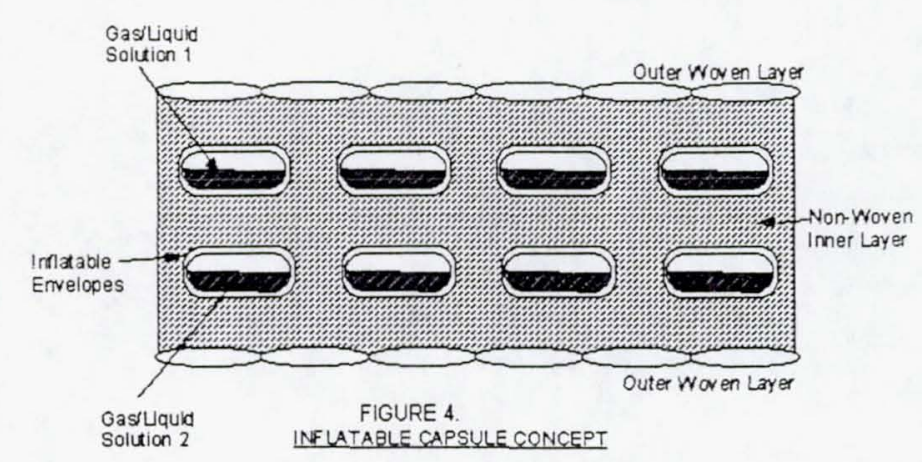

At colder temperatures, gas release from solution is followed by solidification of the solvent, which cause the elements to expand and the thermal conductivity to decrease due to larger thermal paths. A second concept uses a composite structure made of woven outer layers and nonwoven inner layer containing capsules filled with the gas/solvent mixture (figure 4). Advantages of 
soluble-gas elements are the ability to passively control thermal conductivity, and the ability to incorporate them into fabrics.

Table 3. Soluble-Gas Candidate Substances

\begin{tabular}{|c|c|c|c|c|c|}
\hline Solvent & F.P. & $B . P B$ & $\begin{array}{l}\text { Comb } \\
\text { us- } \\
\text { tibility }\end{array}$ & $\begin{array}{l}\text { Toxi- } \\
\text { city }\end{array}$ & Uses \\
\hline Acetophenone & 19.7 & 202 & $\begin{array}{l}\text { Flash= } \\
\text { 180C. } \\
\text { Open } \\
\text { Cp }\end{array}$ & & $\begin{array}{l}\text { Perfumery, solvent, } \\
\text { pharm, flavoring }\end{array}$ \\
\hline t-Butyl Alconol & 25.5 & 82.9 & $\begin{array}{l}\text { Flash= } \\
52 \mathrm{~F} \\
\text { Closd } \\
\text { Cp }\end{array}$ & & $\begin{array}{l}\text { Solvent, alcohol } \\
\text { denaturant, organic syn }\end{array}$ \\
\hline n-Octadecane & 28 & 318 & & irritant & $\begin{array}{l}\text { Solvents, org synthesis, } \\
\text { calibration }\end{array}$ \\
\hline \multicolumn{6}{|l|}{ Dimethyl Adipate } \\
\hline Levulinic Acid & $\begin{array}{l}33- \\
35\end{array}$ & 245 & & & $\begin{array}{l}\text { Interm for plasticizers, } \\
\text { solvents, resins, phar }\end{array}$ \\
\hline 1,2-Dibromoethane & 9.1 & 131 & $\begin{array}{l}\text { Volatil } \\
\text { e, } \\
\text { Non- } \\
\text { flam }\end{array}$ & & $\begin{array}{l}\text { Lead scavenger in gas, } \\
\text { fats solvents, celluloid }\end{array}$ \\
\hline $\begin{array}{l}\text { Phenyl Ether } \\
\text { (diphenyl oxide) }\end{array}$ & 27 & 259 & $\begin{array}{l}\text { Flash= } \\
205 \mathrm{~F}\end{array}$ & & $\begin{array}{l}\text { Org Synth, perfumeryl } \\
\text { soaps, heat transfer mo }\end{array}$ \\
\hline $\begin{array}{l}\text { Urethane (ethyl } \\
\text { carbamate (1) }\end{array}$ & 49 & 180 & & & $\begin{array}{l}\text { Medicine, inter for phar, } \\
\text { pest, fungicides }\end{array}$ \\
\hline Water & 0 & 100 & & & \\
\hline Dimethyisulfoxide & 18.5 & 189 & & irritant & $\begin{array}{l}\text { Powerful solvent /low } \\
\text { tox, indus cleaners }\end{array}$ \\
\hline n-Propylsulfone & 30 & - & & & \\
\hline Tricosane & 48 & 234 & & irritant & Organic synth. \\
\hline$n-D o \cos a n \theta$ & 45.7 & 230 & & irritant & $\begin{array}{l}\text { Org synth, calib temp } \\
\text { sensitive devices }\end{array}$ \\
\hline Formamide & 2.5 & $\begin{array}{l}-200 \\
\text { deco } \\
\text { m } \\
\text { @ 180 }\end{array}$ & & & $\begin{array}{l}\text { Excel solvent, softener, } \\
\text { inter in org synth. }\end{array}$ \\
\hline $\begin{array}{l}1 \text { Hexadecanol } \\
\text { (cetyl alconol) }\end{array}$ & 49.6 & 344 & & irritant & $\begin{array}{l}\text { Medicine, perfumery, } \\
\text { emulsifier, emollient }\end{array}$ \\
\hline Eicosane (2) & 36.7 & 205 & & irritant & $\begin{array}{l}\text { Cosmetics, lubricants, } \\
\text { plasticizers, flm. proofing }\end{array}$ \\
\hline $\begin{array}{l}\text { Polyethylene Glycol } \\
\text { (3) }\end{array}$ & $4-10$ & - & $\begin{array}{l}\text { Fiash = } \\
244 \mathrm{C}\end{array}$ & & $\begin{array}{l}\text { Chemical inter, pharm, } \\
\text { lubricants, cosmetics }\end{array}$ \\
\hline Diphenyl Methane & 26.5 & 265 & & & $\begin{array}{l}\text { Solvent, dyes, } \\
\text { perfumery }\end{array}$ \\
\hline Piperonal & 36 & 263 & & & $\begin{array}{l}\text { Med, perfum, suntan, } \\
\text { flavoring }\end{array}$ \\
\hline
\end{tabular}

Disadvantages are the safety issues with chemicals used for the solvents (see table 3 ), and the relatively high level of thermal conductivity expected as compared to suit requirements.

\section{VACUUM PANELS AND ENCLOSURES -}

Vacuum panels contain partially evacuated compartments that, together with other insulating elements, provide high insulation performance. One such concept is a super insulator developed by the U.S. Dept of Commerce [4] using a Dow Corning polystyrene foam evacuated and enclosed with metal foil. An $R$ value six times that of glass-fiber insulation is claimed. This structure is too stiff for direct use in a space suit. Another version, Vacupanel $\AA_{\text {, from }}$ Vacupanel, Inc. of Xenia, Ohio, has been designed for the refrigerator/freezer in the space station Columbus/ISS module [5]. The panels contain a Dow core and it is claimed that a thermal conductivity of 4 $\mathrm{mW} / \mathrm{m}-\mathrm{K}$ can be achieved at approximately 0.1 torr. The conductivity of this panel is in the order of what's needed for a space suit, but the structure is also stiff and needs further evaluation. Another device that uses a vacuum enclosure to lower thermal conductivity is the reversible vacuum thermal switch from NASA-JPL $[6,7]$. The switch is a gas gap thermal switch which uses an oxygen or hydrogen getter to vary the conductance. The switch is used in a sorption refrigeration system and can achieve switching ratios of 700 or greater. Additional evaluation of this concept is required, but the complexity of the getter system presents similar complexities as the active PCM.

A final concept that has been successful in rigid enclosures is the use of aerogels. Originally developed for uses other than thermal insulation, they can exhibit excellent insulation properties in specific applications. An aerogel is a microfine three-dimensional structure of polymerized or aggregated oxide molecules that is the backbone of a gel [8]. The oxides can be from alkalis, early transition metals, rare earths and silicia and alumina.. At ambient conditions, an aerogel can have a thermal conductivity of approximately $17 \mathrm{~mW} / \mathrm{m}-\mathrm{K}$. Much of the conductivity is due to gaseous heat transfer, since the aerogel has limited solids and points of contact. In a vacuum ( $\sim 50$ torr), the thermal conductivity can be decreased to approximately $8 \mathrm{~mW} / \mathrm{m}-\mathrm{K}$. For a suit application, an aerogel would have to be contained in a rigid enclosure, whether evacuated or not, to prevent structural breakdown of the aerogel during movement of the suit.

In general, vacuum enclosures have good potential for lowering the thermal conductivity at reduced pressure. Their drawbacks include weight, volume, and complexity.

FIBROUS MATERIALS - Fibers are widely used for winter clothing since the insulating performance of fibers is the highest for garment applications. Their superior performance is widely thought to be due to their high loft characteristics (high void fractions), but is actually a combination of parameters which includes fiber diameter. Fibrous materials reviewed include a synthetic down developed by Albany, Intl [9]. It uses 80 to $90 \%$ polyester microfibers with a diameter between 3 and 12 microns, and 5 to $20 \%$ thermoplastic macrofibers with a diameter between 12 and 50 microns. From testing and analysis, it was found that the higher density fabrics (lower void fractions) within a certain density range actually provided the best insulation performance. An example of this was shown in testing at JSC (see figure 5 ). The high performance at higher fabric densities can be attributed to the small fiber diameter as is discussed in a subsequent paragraph. Other insulating fibers that perform similar to the Albany fiber (Primaloft $\circledast$ ) include Liteloft ${ }^{\mathrm{TM}}$, Microloft ${ }^{\circledR}$, Comforel $($, Polarguard $\left(\AA\right.$, Quallofil $\left(囚\right.$, and Thinsulate ${ }^{\mathrm{TM}}$. The Albany fiber has the highest $R$ value and lowest compression set for the same fabric density, or denier.

To understand the fundamental mechanisms of heat transfer through fibers, numerous sources from the 
literature were surveyed. An important distinction of textile structures is that they are not homogenous solids, so their measured thermal conductivity is an apparent property affected by three modes of heat transfer. Conduction occurs in both the fiber material and the gas trapped between the fibers. Free convection due to the

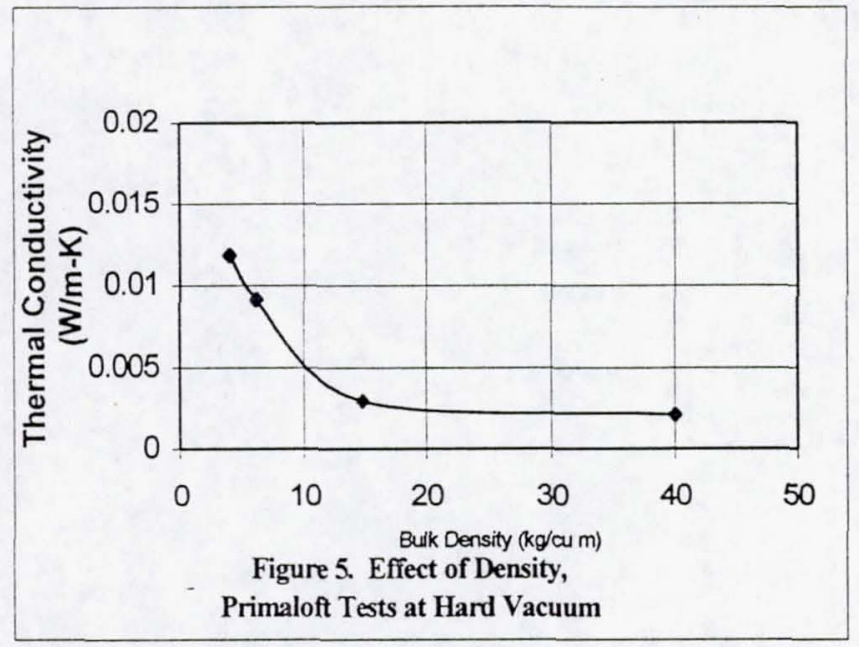

presence of gravity can occur between gas in contact with a solid surface if the Raleigh Number, a function of continuous gas space, is large enough. The third mode of heat transfer, radiation, occurs through the openings in the fabric. Overall, radiation is influenced by the mean number of absorptions and re-emissions of the heat rays passing through the textile layer. A compromise is needed between minimum fiber content for minimum conduction and the amount of fiber necessary to prevent convection and reduce radiation.

It then follows that the design of thermally insulating fibrous structures is driven by parameters such as fiber size and fabric density as a function of fiber/void fraction. In general, the observations made from the studies are that as fabric density increases, thermal conductivity decreases $[10,11,12,13]$. Also in the case of low-density materials, radiation is of greater importance and lower density materials lead to higher values of effective thermal conductivity $[10,14]$. At low pressures, in particular, conduction through residual gases decreases and radiation heat transfer increases and becomes predominant [14].

Fiber diameter affects radiant heat transfer since for a given packing fraction, the finer the fiber, the lower the heat transfer by radiation $[15,16]$. Fine fibers cover better than coarse fibers with a higher surface area-tovolume ratio and greater amount of reflection [17]. In addition, Mathes et al. demonstrated that the radiation extinction coefficients for irradiance perpendicular and oblique to the fibers, varies with temperature and fiber diameter [14].

Finally, it is also important to note that no single model applies to all fabric densities. For evacuated optically thin insulation such as that in low-density fiber mats, the calculation of apparent thermal conductivity is more complex. The complex coupling of these terms is shown by Fricke and Caps, who developed a thermal conductivity model as a function of temperatures, fiber densities, boundary emissivities, and optical thickness [18].

\section{SUMMARY OF SUIT INSULATION TEST PROGRAMS AND RESULTS}

Various studies have been conducted by NASA to evaluate candidate Mars insulations from 1993 to 1999 , and are continuing. The test objectives are presented in Table 4. The test apparatus has been a guarded hotplate instrument in a vacuum chamber. Test gases were air, $\mathrm{CO} 2$, argon, and nitrogen, and test pressures were approximately $10^{-6}$ torr to atmospheric. Argon was used in place of $\mathrm{CO} 2$ for cold Mars environment simulations to prevent $\mathrm{CO} 2$ frost in cold regions of the test apparatus. For all trend data as a function of pressure, the conductivity of the samples tested followed the traditional " $S$ " curve variation with pressure as observed in cryogenic insulations, as extrapolated from [19] (see figure 6 ).

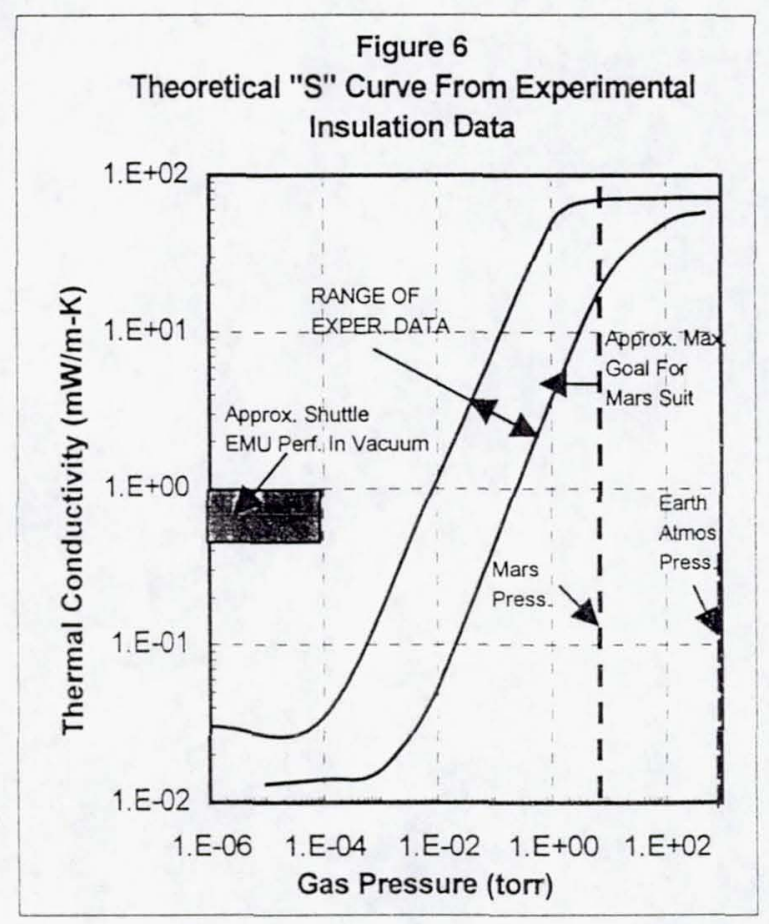

Early studies with Nomex®, an aramid non-woven fabric, were conducted to evaluate the thermal conductivity performance of a particular fibrous structure's dependence on fill-gas pressure. Thermal conductivity was relatively low $(\sim 15 \mathrm{~mW} / \mathrm{m}-\mathrm{K})$, but the Nomex® was not integrated with a suit TMG nor tested in a loaded condition at TMG temperatures.

Integrated suit layer/TMG tests were conducted at NASA [20] between 1994 and March 1998 to evaluate various candidate suit insulation structures, which included portions of the Space Shuttle suit insulation 
multi-layer lay-up, also known as the TMG for thermal micrometeroid garment. Initial candidate insulations, which included fibrous samples and spacers from Velcro $\AA$ products, were tested at Mars pressure and higher pressures to determine trends of thermal conductivity versus pressure. All samples were compression loaded to $6.9 \times 10^{3} \mathrm{~N} / \mathrm{m}^{2}$ (1 psi) to simulate the maximum insulation loading due to suit pressure and motion. Of these, a Primaloft $\Theta$ product had the best performance at Mars pressure.

TABLE 4.

PRIOR TESTS AT CTSD/JSC

\begin{tabular}{|l|l|}
\hline TEST SERIES & OBJECTIVES \\
\hline $\begin{array}{l}\text { Nomex Performance, } \\
\text { NASA Grant to Univ. } \\
\text { of Houston, 1993 }\end{array}$ & $\begin{array}{l}\text { Measure thermal } \\
\text { conductivity of Nomex } \\
\text { versus pressure }\end{array}$ \\
\hline $\begin{array}{l}\text { Integrated Suit Layer } \\
\text { TMG Tests at JSC } \\
\text { 1994 }\end{array}$ & $\begin{array}{l}\text { Test candidate insulations } \\
\text { within Shuttle EMU TMG } \\
\text { configuration }\end{array}$ \\
\hline $\begin{array}{l}\text { Insulation Tests at } \\
\text { EMTL (Energy } \\
\text { Materials Testing } \\
\text { Laboratory, (Maine), } \\
\text { 1997 }\end{array}$ & $\begin{array}{l}\text { Measure conductivity for } \\
\text { sample TMG lay-ups: } \\
\text { Velcron-Coin, Primaloft } \\
\text { (PL1), Primaloft (PL2), } \\
\text { Airloft, Pyroloft }\end{array}$ \\
\hline $\begin{array}{l}\text { Fiber Mars Candidate } \\
\text { TMG Tests at JSC, } \\
\text { 1998 }\end{array}$ & $\begin{array}{l}\text { Continue testing Airloft, } \\
\text { Primaloft in a TMG } \\
\text { configuration at Mars } \\
\text { conditions. }\end{array}$ \\
\hline $\begin{array}{l}\text { Primaloft Sport } \\
\text { Coluation at Mars }\end{array}$ & $\begin{array}{l}\text { Obtain trend data due to } \\
\text { pressure and fabric density } \\
\text { on state-of-the-art fibers }\end{array}$ \\
\hline $\begin{array}{l}\text { Hollofil Sample } \\
\text { Evaluation at Mars } \\
\text { Conditions, 1999 }\end{array}$ & $\begin{array}{l}\text { Obtain trend data due to } \\
\text { pressure and density on } \\
\text { hollow fibers with needling } \\
\text { structure }\end{array}$ \\
\hline
\end{tabular}

Subsequent tests in March 1998 [20] were conducted using Airloft $(2$ and representative Primaloft $\Theta$ fibrous insulation layers, again substituted for the MLI layers. Sample compressive loads were $0.69 \times 10^{3} \mathrm{~N} / \mathrm{m}^{2}$ (0.1 psi) to simulate a more nominal TMG load. Samples of Airloft( $\otimes$ Primaloft $($ all showed similar performance of approximately $25 \mathrm{~mW} / \mathrm{m}-\mathrm{K}$ at Mars conditions.

Finally, a test program was initiated starting in summer of 1999 to test the various parameters of fiber materials as related to insulation performance. Fiber materials were selected for this program because the lofty nature of non-woven fabrics makes them the leading insulator for clothing and flexible structures. These fiber structures were tested wihout the other TMG layers of the suit to obtain comparative data between fiber structures. Even so, the resulting thermal conductivity can be expected to be the predominant one in a TMG layup. The first material selected was a synethic down fabric called Primaloft(B) Sport, from

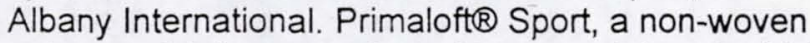
polyester fabric, was selected because it has the highest $R$ value of lofty insulations and the highest recovery from compression. It uses a bonding agent to hold the fibers together. Definite trends were observed due to pressure, with minimum conductivity occuring at high vacuum (see figure 7 ). The highest performance was obtained at the highest density for this material, but the conductivity at Mars conditions was still much higher than $\mathrm{MLI}$ at vacuum.

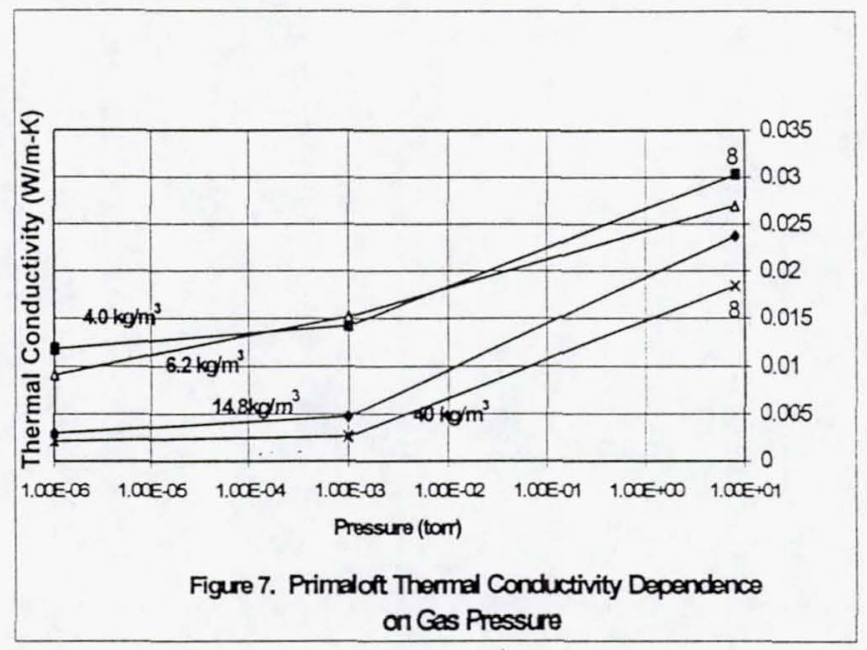

The second fiber selected and tested during the winter of 1999 was a non-woven structure, Hollofil $₫$ from Dupont. It was held together by needling the fibers at two levels of needling intensity: $120 \mathrm{NPI}$ (needles per inch) and $240 \mathrm{NPI}$. Similar trends of thermal conductivity versus pressure and density were seen as with Primaloft 8 Sport, but the thermal conductivity at Mars conditions was somewhat higher for the samples tested (see figure 8).

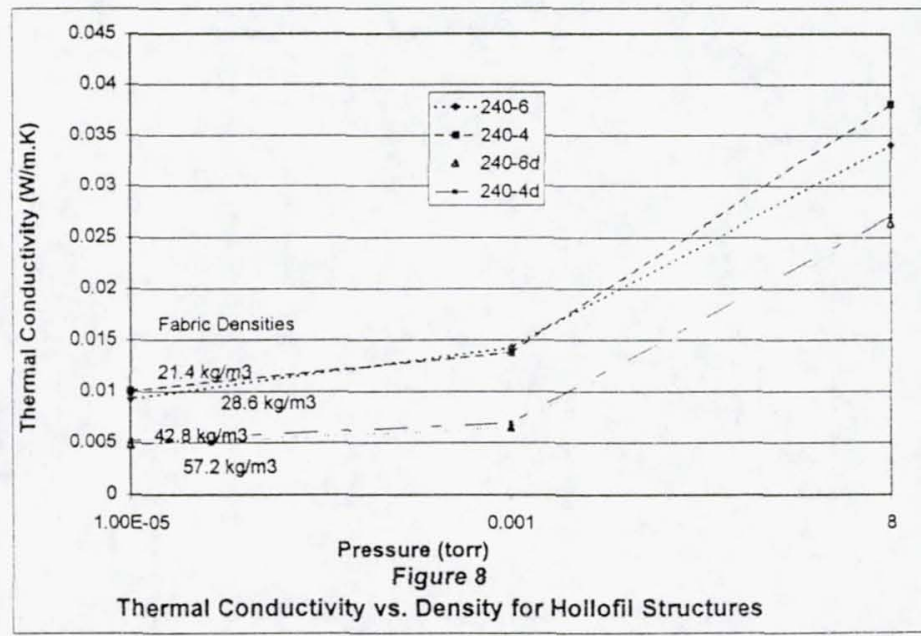

From the test data of all samples tested, it is concluded that none give adequate thermal performance at Mars conditions within current suit bulk requirements. The high loft fibers were the better performers, with a low conductivity of $18 \mathrm{~mW} / \mathrm{m}-\mathrm{K}$ at Mars pressure. This is in contrast to approximately $1.6 \mathrm{~mW} / \mathrm{m}-\mathrm{K}$ from Shuttle EMU MLI at vacuum shown in figure 6 , which in turn provides the required conductance of $0.62 \mathrm{~W} / \mathrm{m} 2-\mathrm{K}$ in vacuum conditions. Assuming the same conductance for a Mars fiber insulation as that of the Shuttle EMU, the required thickness of the best fiber insulation results in a 
factor of at least 12 times the thickness of the Shuttle insulation. This in turn corresponds to a bulk TMG of about $2.90 \mathrm{~cm}$ (1.14 inches). The current goal requirement for bulk is $1.27 \mathrm{~cm}$ maximum ( 0.5 inches).

\section{SUIT INSULATION DEVELOPMENT PHILOSOPHY}

EVA PRODUCTIVITY VS. BULK - To the casual observer, it would seem that an advanced suit for Mars should be a streamlined, lightweight version of previous suits, owing to the experience gained since Apollo. But many practical limitations arise in Mars that don't exist in a vacuum or on earth. One earth-based analogy to a Mars insulation in cold environments is the use of protective parkas in Antarctica. These parkas are about one inch thick with additional layering underneath. As with any cold weather clothing, there is some loss of productivity of the user due to bulk, even without the presence of a pressurized suit.

In a planetary EVA application, mobility is a major factor in a crewmember's productivity, with mobility during walking being one more requirement as compared to low-earth-orbit EVA's. But decreased mobility is primarily due to the pressurized suit which causes resistance to movement. This is also true for the Shuttle EMU suit which presents mobility restrictions even with a flat TMG surface of approximately $0.127 \mathrm{~mm}$ (0.1 inch), and with its high mobility waist and arm bearing joints that weren't there for the Apollo suits. Adding bulk to the outside of the suit (over one inchcurrent projections) can only decrease the effectiveness of work for the EVA crewmember because he/she must not only account for the resistance and bulk inherent in a pressurized suit, but for extra bulk needed for thermal insulation.

Other bulk impacts result from the need to build only one EVA suit for Mars. There are cost and stowage advantages for the planetary suit to be the same suit used for EVA from the interplanetary spacecraft. The bulky planetary suit, bulkier than needed for vacuum EVA, would require more stowage space in the spacecraft as well as more cabin space for movement in and around the cabin. Therefore added bulk on the suit is contrary to cost and launch weight restrictions. To reduce these impacts and other productivity impacts, the current maximum thickness goal for TMG bulk is 1.27 $\mathrm{mm}$ ( 0.5 inches).

BULK COMPARISONS - From the initial tests and surveys of candidate insulation concepts, an effort was made to provide adequate thermal insulation in a low pressure gaseous environment while keeping the suit insulation within thickness used for earth-based garments. Table 5 was produced to compare thickness equivalent to a particular conductance or heat leak through the suit. For some concepts, no thickness is shown due to lack of design data. In one concept, the Mars panels, the thickness assumes linearity with the conductance for a large spacecraft composite insulation which may not be scalable down to suit thickness. For the Vacupanel ${ }^{\circledR}$ design, this structure uses rigid materials and, although it has the lowest conductivity of the configurations surveyed, it cannot be directly used for the soft areas of a suit. Fiber materials and phase change materials show the lowest achievable insulation thickness of approximately one

TABLE 5 .

THERMAL CONDUCTIVITY \& BULK COMPARISONS FOR MARS INSULATION

\begin{tabular}{|c|c|c|}
\hline INSULATION CONCEPT & $\begin{array}{l}\text { REPORTED } \mathrm{k} \\
(\mathrm{mW} / \mathrm{m}-\mathrm{K})\end{array}$ & $\begin{array}{l}\text { EXPECTED } \\
\text { INSULATION } \\
\text { THICKNESS (mm/inch) }\end{array}$ \\
\hline $\begin{array}{l}\text { 1. Porous Mars Composite } \\
\text { Panels }\end{array}$ & $\begin{array}{l}10 \text { to } 15 \text { in Mars } \\
\text { Press. }\end{array}$ & $\begin{array}{l}24 \mathrm{~mm} / 0.95 \text { in } \\
\text { theoretical only }\end{array}$ \\
\hline $\begin{array}{l}\text { 2. Phase Change Matls } \\
\text { a) Hexcadecane, } 64 \mathrm{~F} \\
\text { melt }\end{array}$ & N/A & $\begin{array}{l}-0.7 \text { inch total with } 20 \\
\text { lb. Penalty }\end{array}$ \\
\hline b) Water, $32 \mathrm{~F}$ melt & N/A & $\begin{array}{l}\sim 1 \text { inch total with } 10 \mathrm{lb} \\
\text { penalty }\end{array}$ \\
\hline 3. Hollow Spheres & 6010200 & $\begin{array}{l}96 \mathrm{~mm} \text { to } 322 \mathrm{~mm} \\
\text { (3.8 to } 12.7 \mathrm{in})\end{array}$ \\
\hline 4. Soluble Gas Elements & $\begin{array}{l}\text { Unknown, but } \\
\text { expected high at } \\
\text { Mars pressure }\end{array}$ & - \\
\hline $\begin{array}{l}\text { 5. Vaculum Enclosure } \\
\text { a) Vacupanel } \\
\text { b) Gas Gap Switches }\end{array}$ & $\begin{array}{l}4 @ 0.1 \text { torr } \\
\text { Potential for very } \\
\text { low conductivities }\end{array}$ & $\begin{array}{l}6 \mathrm{~mm} / .003 \text { in, theoretical } \\
\text { only } \\
\text { No available values }\end{array}$ \\
\hline 6. Fibrous Materials & $\begin{array}{l}18 @ \text { Mars } \\
\text { conditions }\end{array}$ & $29 \mathrm{~mm} / 1.14 \mathrm{in}$. \\
\hline
\end{tabular}

inch. This value will undoubtably grow to compensate for thermal shorts in joints and compressed areas of the suit. In addition to thermal performance, an evaluation of the pros and cons of all insulation candidates is presented in the next section.

INSULATION RANKINGS - To aid with the insulation philosophy, a ranking was developed using the concept selection matrix method from Stuart Pugh. Nine insulation concepts were categorized from possible concepts for suit application. Passive phase materials were grouped in one category, with active phase change materials grouped separately in a category with heat pipes, since both have similar control features. Active heaters were grouped in one category as a replacement for at least a portion of suit insulation, although heaters are technically not insulators. The raw scores are shown as 0 's, +1 's, and -1 's. All categories were ranked relative to $\mathrm{MLI}$ performance at Mars pressure. Categories ranked better than $M L I$ received $a+1$, and those ranked worse than $M L I$ received $a-1$. The final rankings after a weighing factor was applied to each category are shown in the overall ranking row, with the highest having a score of 1 .

Fiber structures were ranked the highest, with active phase change materials and heat pipes ranked the lowest. Foams were second, and MLI, surprisingly was ranked as third. One possible reason for most concepts ranking below MLI is that confidence has not been demonstrated in a suit application for the remaining concepts, such as low weight and flexible attributes 
needed in a suit insulation. In other words, their technology readiness levels for suit application are low. Evaluations will be continued to determine if any of the low ranked concepts should be pursued further. For example, vacuum jackets, with a ranking of 6 , could at least be used on hard parts of the suit without much weight or volume penalties, assuming the final suit is a hybrid with hard parts (torso and brief areas). Passive phase change materials, ranked 5 , are also possible if they can be used safely and do not impose large weight, volume, and regeneration penalties.

\begin{tabular}{|c|c|c|c|c|c|c|c|c|c|c|}
\hline & \multirow[b]{2}{*}{$\begin{array}{l}\text { Fiber } \\
\text { Struc }\end{array}$} & \multirow[b]{2}{*}{ Sphere } & \multirow[b]{2}{*}{ Foam } & \multicolumn{4}{|c|}{$\begin{array}{l}\text { TABLE 6. INSULATION } \\
\text { RANKING MATRIX }\end{array}$} & \multirow[b]{2}{*}{$\begin{array}{c}\text { ACt } \\
\text { PCM, } \\
\text {. Ht } \\
\text { Pipe }\end{array}$} & \multirow[b]{2}{*}{$\begin{array}{l}\text { Sol } \\
\text { Gas } \\
\text { Elem }\end{array}$} & \multirow[b]{2}{*}{$m$} \\
\hline & & & & $\begin{array}{l}\text { Phase } \\
\text { Chg } \\
\text { Matls }\end{array}$ & $\begin{array}{l}\text { Vac } \\
\text { Jac }\end{array}$ & MLI & $\begin{array}{l}\text { Act } \\
\text { Htrs }\end{array}$ & & & \\
\hline $\begin{array}{l}\text { Versatility in } \\
\text { Structure } \\
\text { Configuration }\end{array}$ & 1 & -1 & 1 & -1 & -1 & 0 & 0 & -1 & -1 & 5 \\
\hline $\begin{array}{l}\text { Choice of } \\
\text { Materials }\end{array}$ & 1 & 0 & 1 & 1 & 1 & 0 & 1 & 1 & 1 & 2 \\
\hline $\begin{array}{l}\text { Maturity of } \\
\text { Industry }\end{array}$ & 1 & 1 & 1 & 1 & -1 & 0 & 1 & -1 & -1 & 4 \\
\hline $\begin{array}{l}\text { Insulation } \\
\text { Experience }\end{array}$ & 1 & -1 & 1 & -1 & -1 & 0 & 1 & -1 & -1 & 3 \\
\hline $\begin{array}{l}\text { Flexibility of } \\
\text { Structure }\end{array}$ & 1 & 0 & 0 & 0 & -1 & 0 & 0 & -1 & 1 & 10 \\
\hline $\begin{array}{l}\text { Mechanical } \\
\text { Strength of } \\
\text { Structure }\end{array}$ & 1 & -1 & 1 & -1 & -1 & 0 & 0 & -1 & 0 & 5 \\
\hline $\begin{array}{l}\text { Continuity of } \\
\text { Structure }\end{array}$ & 1 & -1 & 1 & 1 & 1 & 0 & 0 & 0 & 1 & 2 \\
\hline Thickness & 1 & 0 & 1 & 1 & 1 & 0 & 1 & 0 & -1 & 10 \\
\hline Mass & 1 & -1 & 1 & -1 & 1 & 0 & -1 & -1 & -1 & 10 \\
\hline $\begin{array}{l}\text { Passive } \\
\text { Nature \& } \\
\text { Maintainability }\end{array}$ & 1 & -1 & 1 & -1 & -1 & 0 & -1 & -1 & 0 & 5 \\
\hline Robustness & 1 & -1 & 1 & 1 & -1 & 0 & -1 & -1 & 0 & 10 \\
\hline $\begin{array}{l}\text { Safety / } \\
\text { Contamina- } \\
\text { tion / Health }\end{array}$ & 0 & -1 & 0 & 0 & 0 & 0 & -1 & -1 & -1 & 10 \\
\hline Performance & 1 & -1 & 0 & -1 & 0 & 0 & 1 & 0 & -1 & 10 \\
\hline $\begin{array}{l}\text { OVERALL } \\
\text { RANKING }\end{array}$ & 1 & 8 & 2 & 5 & 6 & 3 & 4 & 9 & 7 & \\
\hline
\end{tabular}

EVACUATED FIBER ELEMENTS - Since it has been demonstrated that the highest insulation values occur at vacuum conditions for multi-layer and other layered structures, including fibers, it follows that some effort should be devoted to bring up the technology readiness of concepts that take advantage of the vacuum. One candidate being pursued is hollow fibers which can be evacuated and then sealed. They have been selected as a starting point because fibers already possess many advantages. They can be woven into a structure or easily contained within layers of other structures. In principle, this appears feasible, but there are practical barriers. Manufacturing of such structures is one. A second challenge is containing the vacuum, that is, preventing inward leaks through the fiber walls, so that the insulation performance is not degraded over time.

If hollow fibers are not practical, then other evacuated elements containing fibers should be pursued. Solid fibers will still provide excellent insulation properties when surrounded by vacuum, as demonstrated with Primaloft $\circledast$ and Hollofil $\circledast$ fibers. Secondary structures should be explored that contain both the vacuum and the fibers, and have flexible features needed for soft suit elements.

\section{CONCLUSIONS}

This feasibility study was conducted to establish an advanced space suit insulation development philosophy. Key areas required for this study are an understanding of the insulation requirements for a suited crewmember in a Mars environment, a survey of candidate insulation concepts for suit application, a review of test data from insulation tests at Mars conditions, and a ranking exercise of all candidate insulation concepts. From evaluations in these key areas, fiber structures were selected as the favored insulation. However, available test data and mission/EVA operational constraints indicate the need to reduce the expected bulk of an inch or more in Mars cold environments. Therefore, it is recommended that evacuated fiber elements be pursued to reduce the bulk to 0.5 inches or less by taking advantage of high insulation properties at vacuum conditions.

\section{ACKNOWLEDGEMENTS}

Gratitude is expressed to the following individuals who helped make this work possible: Edward Vaughn of Clemson University for design and fabrication of nonwoven samples; Bill Keeling of GB Tech for day-to-day operations on the guarded hot plate and vacuum controls; Henry Tang of GB Tech for coordination of fiber insulation tests; Lockheed Martin personnel and in particular, John lovine for thermal analysis support; Gretchen Thomas for programmatic support; and the JSC-CTSD Advanced EVA team for assistance with suit insulation development philosophy.

\section{REFERENCES}

1. "Preliminary Design Review, Advanced Technology Spacesuit Thermal Module, Lockheed Martin Space Operations, J. lovine and R. Horton, NAS9-19100, September 30, 1999."

2. W.P.P. Fischer, et al, Porous Insulation Performance Under Martian Environment, $23^{\text {rd }}$ ICES Conference, No. 932116, July 12, 1993.

3. U.S. Patent No. 1,270,216, Temperature Adaptable Fabrics, J.P. Stevens \& Co, Inc, April 1970.

4. Arthur Fischer, "Super Insulator, Popular Science Article, Dec 1998

5. J. Winter, et al, The Refrigerator/Freezer Rack for the International Space Station, $29^{\text {th }}$ ICES Conference, No. 1999-01-1943, July 12, 1999.

6. Reversible Chemisorption Gas-Gap Thermal Switch, Technical Support Package for NASA Tech Briefs, from JPL Invention Rpt NOP-17568/7076, J. Jones, 
S. Bard, G. Blue, JPL technology Utilization Office, Jet Propulsion laboratory, Pasadena, Ca., Nov 1991.

7. D.L. Johnson, J.J. Wu, Feasibility Demonstration of A Thermal Switch For Dual Temperature IR Focal Plane Cooling, Jet Propulsion Laboratory, California Pasadena, Ca., Proceedings For $9^{\text {th }}$ International Cryocooler Conference, June 25, 1996.

8. Aerogels, Presentation at NASA Crew and Thermal Systems Division, by Walt Vonau Jr., Advanced Materials Lab, Sept 23, 1999.

9. James Donavan, Synthetic Down, US Patent No. 4,588,635, Mar 1986.

10. S. Baxter, The Thermal Conductivity of Textiles, Phys. Soc. LVIII, I, Sept. (1945)

11. J. D. Verschoor, P. Greebler, and N. J. Manville, Heat Transfer bt Gas Conduction and Radiation in Fibrous Insulations, Transactions of the ASME, 74, 6, 961 (1952)

12. J. O. Ukponmwan, Textile Progress, 24, 4 (1993)

13. D. Fournier and S. Klarsfeld, Some Recent Experimental Data on Glass Fiber Insulating Materials and Their Use for a Reliable Design of Insulations at low Temperatures, Heat Transmission Measurements in Thermal Insulations, ASTM STP 544, American Society for Testing and Materials, 223 (1974)

14. R. Mathes, J. Blumenberg, K. Keller, Radiative Heat Transfer in Insulations with Random Fibre Orientation, J. Heat Mass Transfer, 33, 4, 767 (1990)

15. B. Farnwoth, Mechanisms of Heat Flow Through Clothing Insulation, T.R.J., No. 12, 717, (1983).

16. R.W. Dent, J.G. Donavan, J. Skelton, and S. Fossey, "Development of Synthetic Down Alternatives," technical report NatickTR-86/0212, (1984).

17. S. Warner, Fiber Science, Prentice Hall, Englewood Cliffs, NJ (1995)

18. J. Fricke and R. Caps, Heat Transfer in Thermal Insulations-Recent Progress in Analysis, Int. J. Thermophysics, 9, 5 (1988)

19. Peter Glaser et al, Thermal Insulation Systems, A Survey, A.D. Little Inc., NASA Contract, NASA SP5027, Technology Utilization Office, Washington, D.C., 1967.

20. Advanced Suit Insulation Materials Status at Crew and Thermal Systems Division, Internal NASAJJSC Review, Luis Trevino and Evelyne Orndoff, July 1999.

\section{ACRONYMS}

EMU Extra-Vehicular Mobility Unit

EVA Extra-Vehicular Activity

MLI Multi Layer Insulation

JSC Johnson Space Center

PCM Phase Change Material

TMG Thermal Micro-meteoroid Garment 